\title{
recillunds
}

Revista Científica Mundo de la Investigación y el Conocimiento

\author{
Nefi Manuel Galán Cherrez a ; Jeimi Patricia Maya Montalvan ${ }^{\text {b; }}$ Oswaldo Edison \\ Garcia Brito ${ }^{c}$; Steffany Katherine Montece Ochoa ${ }^{d}$
}

The Use of Supplementary Materials for Teaching Children in EFL Classes

El uso de materiales suplementarios para el proceso de enseñanza a los niños en las clases de EFL.

Revista Científica Mundo de la Investigación y el Conocimiento. Vol. 2 núm.4, Octubre, ISSN: 2588-073X, 2018, pp. 139-159

DOI: 10.26820/recimundo/2.(4).octubre.2018.139-159

URL: http://recimundo.com/index.php/es/article/view/343

Editorial Saberes del Conocimiento

Recibido: 15/07/2018

Aceptado: 05/08/2018

Publicado: 30/10/2018

Correspondencia: nephi1985@gmail.com

a. Magister en Enseñanza de Inglés como Lengua Extranjera; Licenciado en Ciencias de la Educación mención Ingles; Universidad de Guayaquil; nefi.galanch@ug.edu.ec

b. Magister en Enseñanza de Inglés como Lengua Extranjera; Licenciada en Ciencias de la Educación Mención Lengua Inglesa y Lingüística; Universidad de Guayaquil; jeimi.mayam@ug.edu.ec

c. Magister en Enseñanza de Inglés como Lengua Extranjera; Diploma Superior en Diseño Curricular por Competencias; Magister en Diseño Curricular; Ingeniero Agrónomo; Universidad de Guayaquil; oswaldo.garciab@ug.edu.ec

d. Ingeniera en Gestión Empresarial de la Universidad de Guayaquil. 


\title{
The Use of Supplementary Materials for Teaching Children in EFL Classes
}

Vol. 2, núm. 4., (2018)

Nefi Manuel Galán Cherrez; Jeimi Patricia Maya Montalvan; Oswaldo Edison Garcia Brito; Steffany Katherine Montece Ochoa

\begin{abstract}
This research project is about the use of supplementary materials for teaching children in EFL classes. The purpose of this study is to find out whether educators in Ecuador are using supplementary materials for the teaching of English as a foreign language or if they are not using them at all. In addition, the use of supplementary materials enhances children's performance because they learn through interaction with these tools.

The investigation took place in the city of Loja at a private institution where English is taught to people from all ages and levels. The general approach of this study is Qualitative and Quantitative. The aspects taken into account for the qualitative analysis were: pertinence, appropriateness, and quality of each supplementary material in every observed class. Furthermore, the aspects that were taken into consideration for the quantitative analysis were: frequency of use of each supporting material; personal criteria based on observation, surveys and interviews. Subsequently, the instruments employed in this investigation were data collection formats, observation formats, tables and questionnaires. According to the results, the most used material is the whiteboard.
\end{abstract}

Keywords: Learning; Teaching; Pedagogy; English language. 


\section{The Use of Supplementary Materials for Teaching Children in EFL Classes}

Vol. 2, núm. 4., (2018)

Nefi Manuel Galán Cherrez; Jeimi Patricia Maya Montalvan; Oswaldo Edison Garcia Brito;

Steffany Katherine Montece Ochoa

\section{RESUMEN}

Este trabajo de investigación trata sobre el uso de materiales complementarios para enseñar a los niños en las clases de EFL. El propósito de este estudio es averiguar si los educadores en Ecuador están utilizando materiales complementarios para la enseñanza del inglés como idioma extranjero o si no los están usando en absoluto. Además, el uso de materiales complementarios mejora el rendimiento de los niños porque aprenden a través de la interacción con estas herramientas.

La investigación se llevó a cabo en la ciudad de Loja en una institución privada donde se enseña inglés a personas de todas las edades y niveles. El enfoque general de este estudio es cualitativo y cuantitativo. Los aspectos tomados en cuenta para el análisis cualitativo fueron: pertinencia, adecuación y calidad de cada material complementario en cada clase observada. Además, los aspectos que se tuvieron en cuenta para el análisis cuantitativo fueron: la frecuencia de uso de cada material de apoyo; Criterios personales basados en observación, encuestas y entrevistas. Posteriormente, los instrumentos empleados en esta investigación fueron formatos de recolección de datos, formatos de observación, tablas y cuestionarios. Según los resultados, el material más utilizado es la pizarra.

Palabras claves: Aprendizaje; Enseñanza; Pedagogía; Idioma Ingles. 


\section{The Use of Supplementary Materials for Teaching Children in EFL Classes}

Vol. 2, núm. 4., (2018)

Nefi Manuel Galán Cherrez; Jeimi Patricia Maya Montalvan; Oswaldo Edison Garcia Brito; Steffany Katherine Montece Ochoa

\section{Introduction.}

Teaching English as a foreign language is a matter that most countries all over the world are discussing and putting it into practice. There are certain components that play an essential role in the teaching of English as a foreign language, such as: the socio-cultural component (educational and historical context in which languages are taught); the bibliographical component (content and context of the syllabus), and the methodological component (method and applied resources and techniques of the teaching- learning process).

Educators cannot work alone within the context of the teaching-learning process. They need teaching-learning tools in order to achieve the desired goals. Those teaching-learning aids are the supplementary materials for EFL classes. These materials can be visual, audio, audiovisual, realia, and on-line. The purpose of this study is to find out whether supplementary materials are being used appropriately and pertinently or if they are not used at all.

The specific objectives of this study are: Identify and analyze supporting materials used in EFL classes; describe and analyze each one of the supplementary materials used in EFL classrooms in terms of pertinence (content), appropriateness (students' needs), and quality; and determine the frequency and variety of the supplementary material used in the observed classes. Moreover, the objectives of this study will be focused on the teaching of English to children from 8 to 9 years old.

It is essential to use supplementary materials to teach English to children because they contribute in the process of learning. In addition, since English is a foreign language, it is a challenge for non-native English speakers to acquire it; therefore, learners must be cognitively 


\section{The Use of Supplementary Materials for Teaching Children in EFL Classes}

Vol. 2, núm. 4., (2018)

Nefi Manuel Galán Cherrez; Jeimi Patricia Maya Montalvan; Oswaldo Edison Garcia Brito;

Steffany Katherine Montece Ochoa

engaged in order to use the language and retain it as well. Supplementary materials activate learning and help retain information due to the fact that students' learning styles are taken into consideration.

There have been several studies of the use of supplementary materials for teaching English as a foreign language especially in Asian countries like Taiwan, South Korea, and China. These studies have shown how the media and authentic materials are practical tools to teach English.

Kelsen (2002) investigated how the use of the internet as a supplementary material in EFL classes is changing the way we teach and learn. Since technology is a big part of our lives now, the use of internet is considered as one of the potential materials that could engage students in the learning process. To achieve the purpose of the study, the author explored the use of YouTube in an EFL situation by surveying students' attitudes towards using YouTube to learn English.

During the study, there were some limitations. One of them was that the questionnaires were only written in English. Nevertheless, the educator was present to explain the difficulties that the students had. Another limitation was that the self-reported nature of the survey may have led students to overstate their answers as the teachers administer the questionnaires. Furthermore, the small sample size, especially in female students, made difficult gender comparisons.

Xiao (2007) explained that internet-based desktop videoconferencing offers an authentic learning environment in which language learners can orally and visually interact with another human being in the target language. The purpose of his study was to investigate the effects of 


\section{The Use of Supplementary Materials for Teaching Children in EFL Classes}

Vol. 2, núm. 4., (2018)

Nefi Manuel Galán Cherrez; Jeimi Patricia Maya Montalvan; Oswaldo Edison Garcia Brito; Steffany Katherine Montece Ochoa

interaction with native English speakers via internet-based videoconferencing on EFL learners' language proficiency in terms of fluency, accuracy, and complexity.

In his study there were certain limitations. One of them was that videoconferencing has more resemblance to face-to-face interaction than text-based chatting, and therefore, has more tendencies to be used as an alternative way to substitute for traditional face-to-face interaction. Another limitation was the small sample size. Due to the time difference between USA and China and the limitation of resources, it was not feasible to conduct a large-scale study.

Peacock (1997) investigated that authentic materials such as poems, television listings, short articles, and newspapers increase the classroom motivation of learners. The purpose of the investigation was to assess the value of these authentic materials for teaching English to foreign learners. A limitation of the research was that it takes time to beginning learners to get accustomed to authentic materials because they have not acquired enough lexicon to understand all the information that it is in them. However, once they learn more vocabulary, they will start to enjoy working with authentic materials.

The beneficiaries in this research project will be educators and learners because through it the investigator will awake teachers' interest in using supporting materials in their classes, having as an outcome more encouraging and interesting classes. In addition, there will be an improvement in education because the use of the materials will adapt to the needs of the learners and the ways they acquire knowledge. In short, future generations will enjoy working with these learning tools and English acquisition will be easier and more practical. 


\section{The Use of Supplementary Materials for Teaching Children in EFL Classes}

Vol. 2, núm. 4., (2018)

Nefi Manuel Galán Cherrez; Jeimi Patricia Maya Montalvan; Oswaldo Edison Garcia Brito; Steffany Katherine Montece Ochoa

One limitation found in the study was the lack of authentic materials such as magazines, brochures, leaflets, bus passes, and so on. These kinds of materials can also work as supplementary materials within the process of learning because native English speakers make use of them in everyday life; thus, it is essential to work with them to get a sense of reality in relation to foreign languages.

\section{Method.}

\section{Setting and Participants}

The following study about the use of supplementary materials for teaching English as a foreign language took place in the city of Loja. The sample was taken from a private institution in downtown Loja. The sample was three courses; each of them with a different level was observed and analyzed.

The institution had several groups of children learning English as foreign language; such classes are divided by the students' age and their level of knowledge. The classes that were observed were: Elementary level- Kid's box 2 (8 year-old students approximately); Pre Intermediate level- Kid's box 3 (9 year-old students approximately); and Intermediate levelKid's box 4 (10 year-old students approximately).

\section{Procedures}

The investigation consisted of getting all the information regarding Teaching English as a foreign language, learners, learning styles, teaching techniques, different context for teaching, supplementary materials for teaching English as a foreign language, and previous studies about 


\section{The Use of Supplementary Materials for Teaching Children in EFL Classes}

Vol. 2, núm. 4., (2018)

Nefi Manuel Galán Cherrez; Jeimi Patricia Maya Montalvan; Oswaldo Edison Garcia Brito; Steffany Katherine Montece Ochoa

the use of supplementary materials for EFL and ESL classrooms. The information of the research topic was taken from educational sources like books, magazine articles, journal articles, websites, and so forth. With this information, we would have a general idea of teaching English and all the tools educators need in order to have satisfactory results in EFL teaching.

The applied method for this investigation was qualitative and quantitative. The qualitative analysis consisted in describing the use of the supplementary materials in terms of pertinence, appropriateness, and their quality. On the other hand, the quantitative analysis consisted in describing the frequency of the use of every supplementary material for teaching English to children.

In this field research, 3 courses at a private English institute were chosen in order to do 10 observations per course. Each course had its group of students according to their age and level of knowledge. The first course that was chosen was "Elementary level" with students of 8 years old approximately. The second course was "Pre-intermediate level" with students of 9 years old approximately. The final course that was chosen was "Intermediate level" with students of 10 years old approximately.

The techniques used for this investigation were note-taking and surveys; note-taking because the researchers took notes of all the aspects regarding the use of each supporting material for the teaching of English, and surveys because there were some questions asked to the students and teachers about the quality of the material, the frequency of the use of the supplementary materials, and the importance of having them in classroom settings. Furthermore, 


\section{The Use of Supplementary Materials for Teaching Children in EFL Classes}

Vol. 2, núm. 4., (2018)

Nefi Manuel Galán Cherrez; Jeimi Patricia Maya Montalvan; Oswaldo Edison Garcia Brito;

Steffany Katherine Montece Ochoa

the instruments that were used in this research project were observation formats, tables and questionnaires.

For the tabulation process, 10 observations were made per course (group-level), and since there were 3 courses that were observed, there were 30 observations made. The frequency of the use of each supplementary material was counted in every observed class. Therefore, if a material was used in 5 class-observations out of the 10 observations per group-level, the number of frequency will be the same as in the observations, in this case 5. Using the information from the observed classes, we could classify the different supplementary materials and how frequent they were used in each class.

The analysis of results were carried out in all 3 groups $(8,9,10$ year old groups), then the materials used in each class were described. For analyzing the materials four aspects were considered: pertinence (use of the material in relation to the topic and objective of the class); appropriateness (use of the material in relation to the students' knowledge and age); quality (design and elaboration of the materials), and finally the students' ways of learning.

Concerning the quantitative analysis, in addition to the tabulation process that it was previously mentioned, a point of view on part of the observers and the students was made regarding the variety and the frequency of the use supplementary materials in order to know which materials work best with 8, 9, and 10 year old learners; thus, suggestions will be given to new teachers and also to the ones that do not fully understand the importance of using these materials as often as they should. 


\section{The Use of Supplementary Materials for Teaching Children in EFL Classes}

Vol. 2, núm. 4., (2018)

Nefi Manuel Galán Cherrez; Jeimi Patricia Maya Montalvan; Oswaldo Edison Garcia Brito; Steffany Katherine Montece Ochoa

\section{Result.}

Quantitative Analysis

Throughout the 30 class-observations there was a variety of materials employed for the teaching of the lessons that correspond to visual aids such as: flashcards, maps, pictures, handouts, word cards, and the white board; there are other materials that correspond to audio aid such as: songs, and soundtracks; and material that correspond to audio visual such as: videos and movies.

The most frequently used material from all was the white board, in all the observed classes the teacher managed to explain grammar or exercises with the help of a white board. All the materials used throughout the 30 class observations were: flash cards, maps, pictures, handouts, words cards, whiteboard, songs, dialogues, soundtracks, videos, movies, and an object. 


\section{The Use of Supplementary Materials for Teaching Children in EFL Classes}

Vol. 2, núm. 4., (2018)

Nefi Manuel Galán Cherrez; Jeimi Patricia Maya Montalvan; Oswaldo Edison Garcia Brito;

Steffany Katherine Montece Ochoa

\section{Graphic 1}

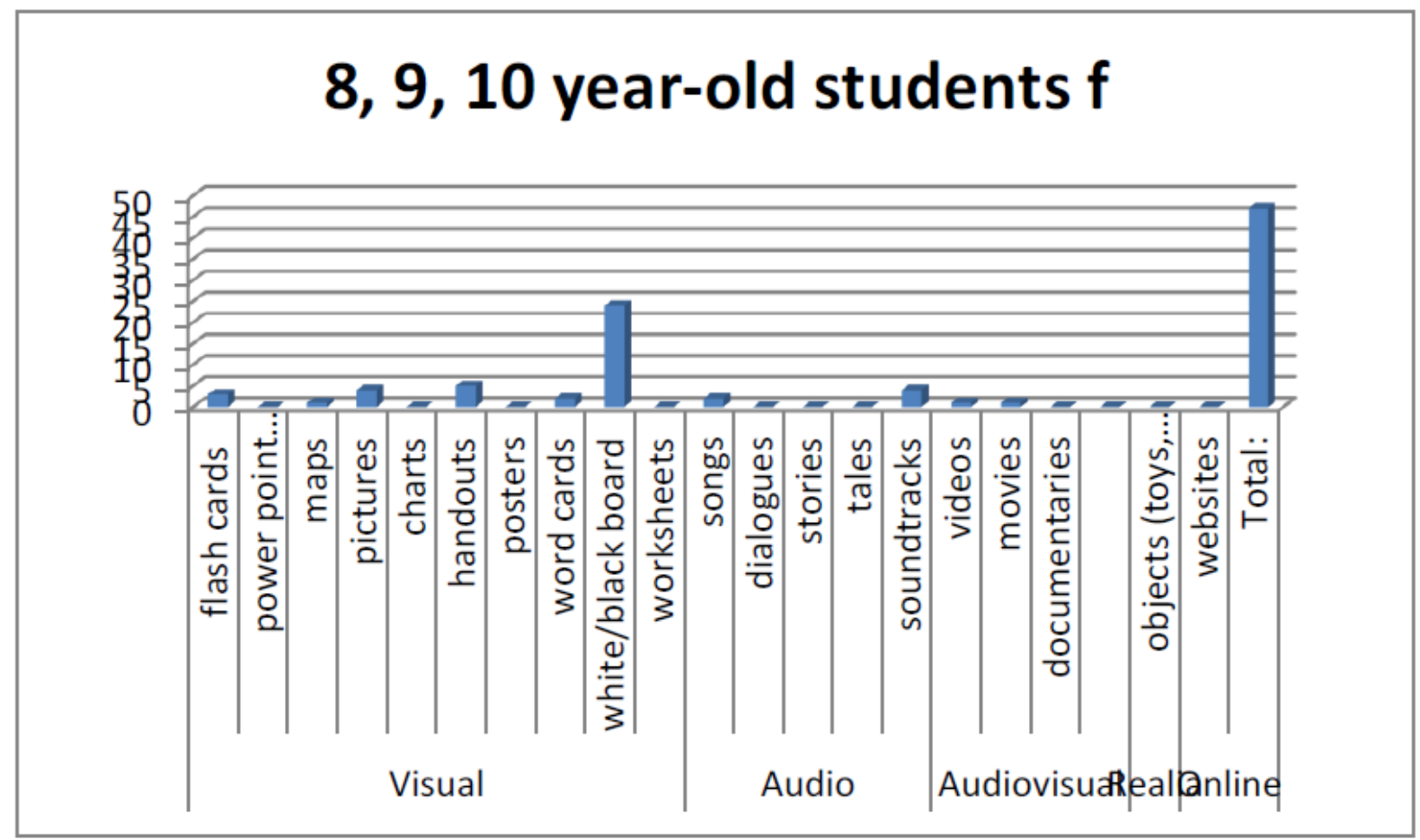

This graphic is a representation of the frequency of the supplementary materials used throughout the 30 class-observations. The whiteboard was used 24 times during the 30 observed classes; handouts were used 5 times; pictures were used 4 times; flashcards were used 3 times; word cards and songs were used 2 times each; maps; and finally videos and movies were used one time. The total of the frequency of used supplementary materials is 47 times throughout the 30 class observations. According to the survey made to the teachers regarding the use of supplementary materials, there is a high range in the use of the whiteboard and it has become in one of the most common materials that is used for teaching.

During the observation of all the classes, it was notorious to see that the whiteboard was the most frequently used material. Teachers tend to use it the most because they have full access 


\section{The Use of Supplementary Materials for Teaching Children in EFL Classes}

Vol. 2, núm. 4., (2018)

Nefi Manuel Galán Cherrez; Jeimi Patricia Maya Montalvan; Oswaldo Edison Garcia Brito; Steffany Katherine Montece Ochoa

to it and can be used anytime during the class. The whiteboard can be helpful when it comes to playing warm up games, to explain a grammatical point, to write down reinforcement exercises, to draw and convey the meaning of a word to students. If the teacher is creative with this tool, by using different colored markers, drawing charts and graphics, distributing the information properly, the students will focus on it and get interested in the class; they will find it as a useful tool for every class.

Handouts, pictures, flashcards are other important materials to be considered in teaching a class. They were colorful, creative and entertaining for the students. The information that they had was easy to understand and encouraged students to participate and be active in class.

According to the surveys held in the classroom, the most interesting types of materials for the children were videos, movies and songs; they would like to have them as frequent as possible. Nevertheless, these materials were the least frequent in the class observations.

The more we get to know our students, the more advantage we will have in the process of teaching English; we must be aware of their likes and dislikes in order to implement them in the class, so that our students get fully engaged in the class. Once we meet this expectation, they will find English a lot easier and pleasant, and will start producing the language. 


\section{The Use of Supplementary Materials for Teaching Children in EFL Classes}

Vol. 2, núm. 4., (2018)

Nefi Manuel Galán Cherrez; Jeimi Patricia Maya Montalvan; Oswaldo Edison Garcia Brito;

Steffany Katherine Montece Ochoa

\section{4th grade ( 8 years old approx.)}

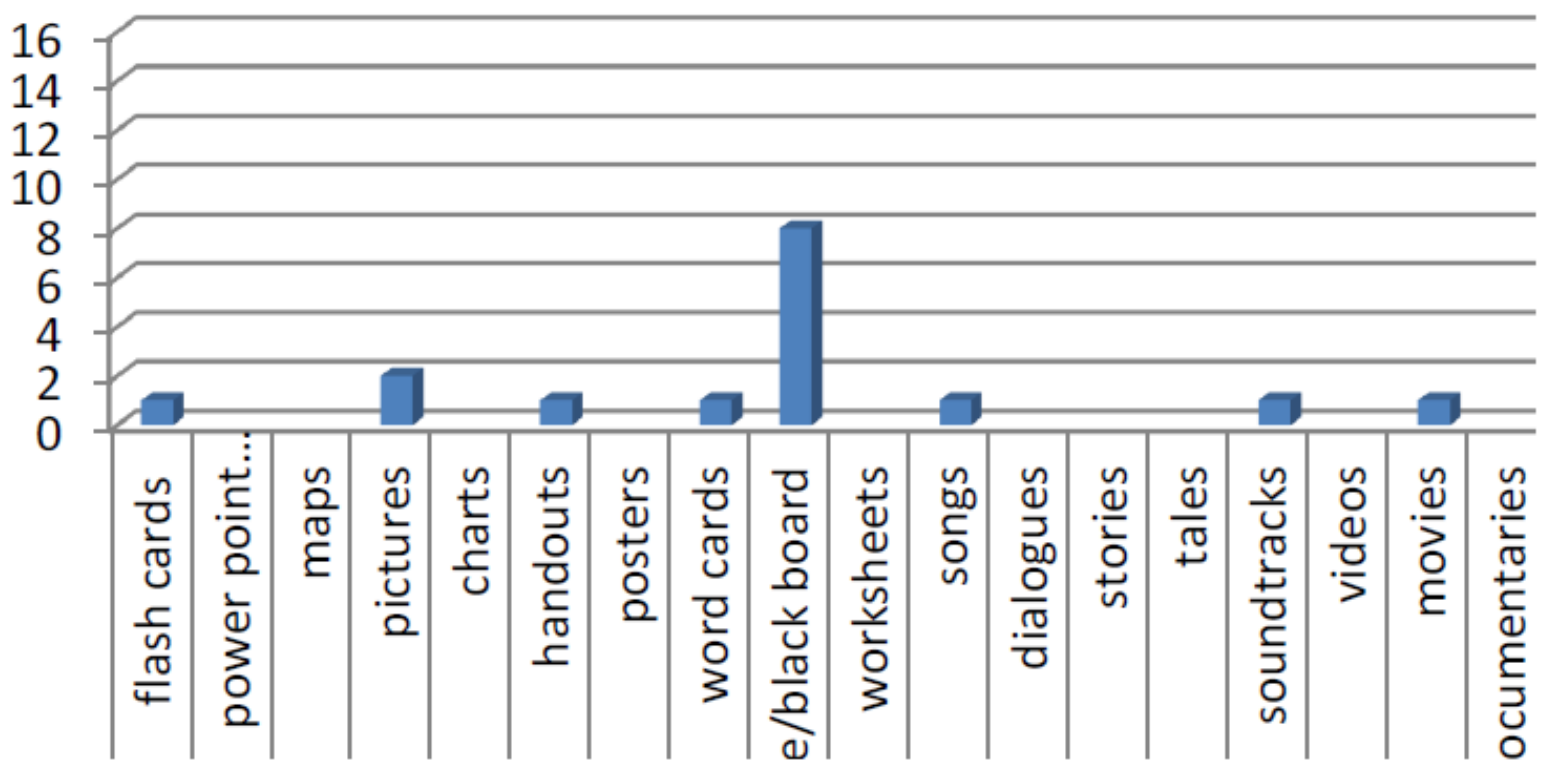

Graphic 4

The second graphic represents the frequency of the use of the supplementary materials with the eight year-old students. According to this graphic we can see that the whiteboard was used 8 times throughout the 10 observed classes; pictures were used twice; then flashcards, handouts, word cards, songs, soundtracks and movies were used once. The total amount of frequency of the materials used during the 10 observed classes was 16; therefore, the teacher used supplementary materials 16 times in the 10 observed classes of the 8 year-old students.

It is evident to see through the graphic that the whiteboard is the supplementary material that it is used the most. In addition, pictures, handouts, among other materials which are part of the visual variables are teaching tools that most students love working to. Audio was also used in 
The Use of Supplementary Materials for Teaching Children in EFL Classes

Vol. 2, núm. 4., (2018)

Nefi Manuel Galán Cherrez; Jeimi Patricia Maya Montalvan; Oswaldo Edison Garcia Brito; Steffany Katherine Montece Ochoa

songs and soundtracks; and a video as part of the audio-visual variable. The students perform better in class as they had more supplementary materials in each class; and also when there was a combination of audio and visual.

Students seem to react better in a class where supplementary materials are applied. As mentioned before, the whiteboard was the most commonly used material due to the fact that every classroom has one; so therefore, it is easier to use and can be employed to point out important information. According to the interviews, students find it better to analyze a grammatical structure or an unknown word once the visualize it, that is when the white board comes in handy.

Another type of visual aid that illustrates the meaning of a word or a phrase is pictures; they have drawings and are multicolored which catches one's attention; with pictures, the learners have more opportunities to become creative and produce a more detailed type of speech.

The other materials used in the 10 observed classes were: flashcards, handouts, word cards, songs, soundtracks and movies; they helped students to be motivated in class and truly understand the information. According to the students' opinion, the use of these materials helped them to make the class more active and amusing, which permitted them to participate in class. Supplementary materials make a class more productive and entertaining for the students and the teacher as well.

We believe that teachers use the white board more times than any other material because it is part of the classroom and it has many uses. The teachers can use it to draw, to explain grammar, to write exercises, to copy reading passages, among other things. It has become the 


\section{The Use of Supplementary Materials for Teaching Children in EFL Classes}

Vol. 2, núm. 4., (2018)

Nefi Manuel Galán Cherrez; Jeimi Patricia Maya Montalvan; Oswaldo Edison Garcia Brito;

Steffany Katherine Montece Ochoa

most frequently used tool because it is like a white sheet of paper and anything can be done with it.

\section{5th grade ( 9 years old approx.) f}

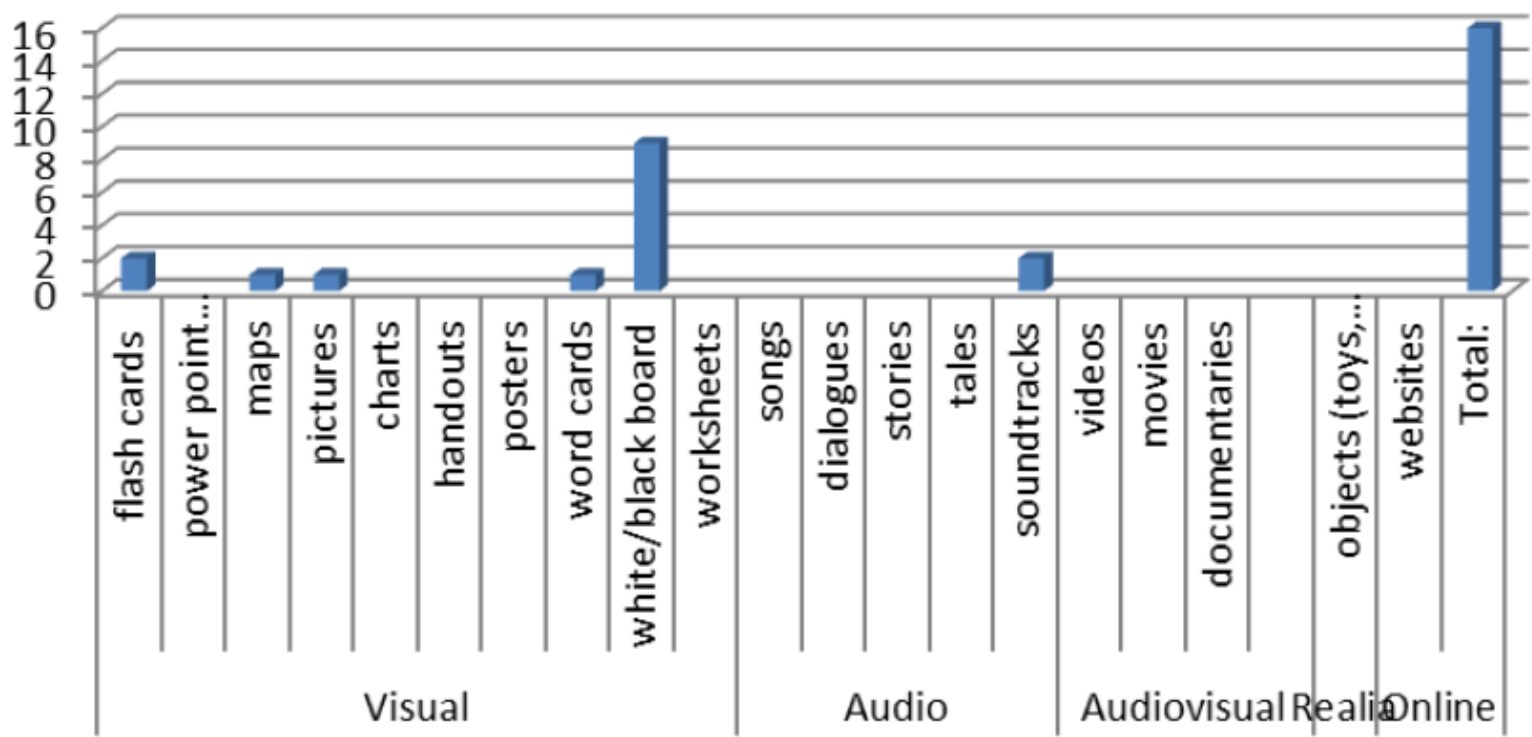

Graphic 3

Chart \#3 represents the frequency of the use of the supplementary materials with the nine year-old students. According to this chart we can see that the whiteboard was used 9 times out of the 10 observed classes; flashcards and soundtracks were used in the classes 2 times each; maps, pictures and word cards were used one time each throughout the 10 class observations; and the total amount of frequency of the material used in the 10 observed classes was 16 ; therefore, the teacher used supplementary materials 16 times throughout the 10 observed classes of the 9 yearold learners. 


\section{The Use of Supplementary Materials for Teaching Children in EFL Classes}

Vol. 2, núm. 4., (2018)

Nefi Manuel Galán Cherrez; Jeimi Patricia Maya Montalvan; Oswaldo Edison Garcia Brito; Steffany Katherine Montece Ochoa

The whiteboard was the most common material that was used followed by flashcards and soundtracks. The visual and audio variables were the ones that took place through these 10 observations. Most students loved working with flashcards and pictures, being one the learning styles where they grasp information and learn the language.

According to the teacher's opinion, children work better when they have some sort of motivation in the classroom, and supplementary material has really helped him to reach this goal. He believes that students need to visualize and hear information in order to adopt in into the new language. Flashcards and pictures were the most appealing material for the children because it had fun drawings and lots of colors; this helped children to develop their creativity and imagination.

Even though the white board was the most used one, it was not very attractive for the children and they did not show any emotion towards it. They found it to be repetitive and just part of every normal class; it was not exciting and did not get their attention as other supplementary materials do.

In our opinion the white board is a tool that can be quite useful in every class; teachers need to know that they can use different colors to make it more fun and interesting. Graphics or drawings should be made to illustrate actions, feelings, and to convey different expressions in general. A good distribution of the board can help to make it attractive to the students and to invite them to be motivated in class. 


\section{The Use of Supplementary Materials for Teaching Children in EFL Classes}

Vol. 2, núm. 4., (2018)

Nefi Manuel Galán Cherrez; Jeimi Patricia Maya Montalvan; Oswaldo Edison Garcia Brito;

Steffany Katherine Montece Ochoa

\section{6th grade (10 years old approx.) f}

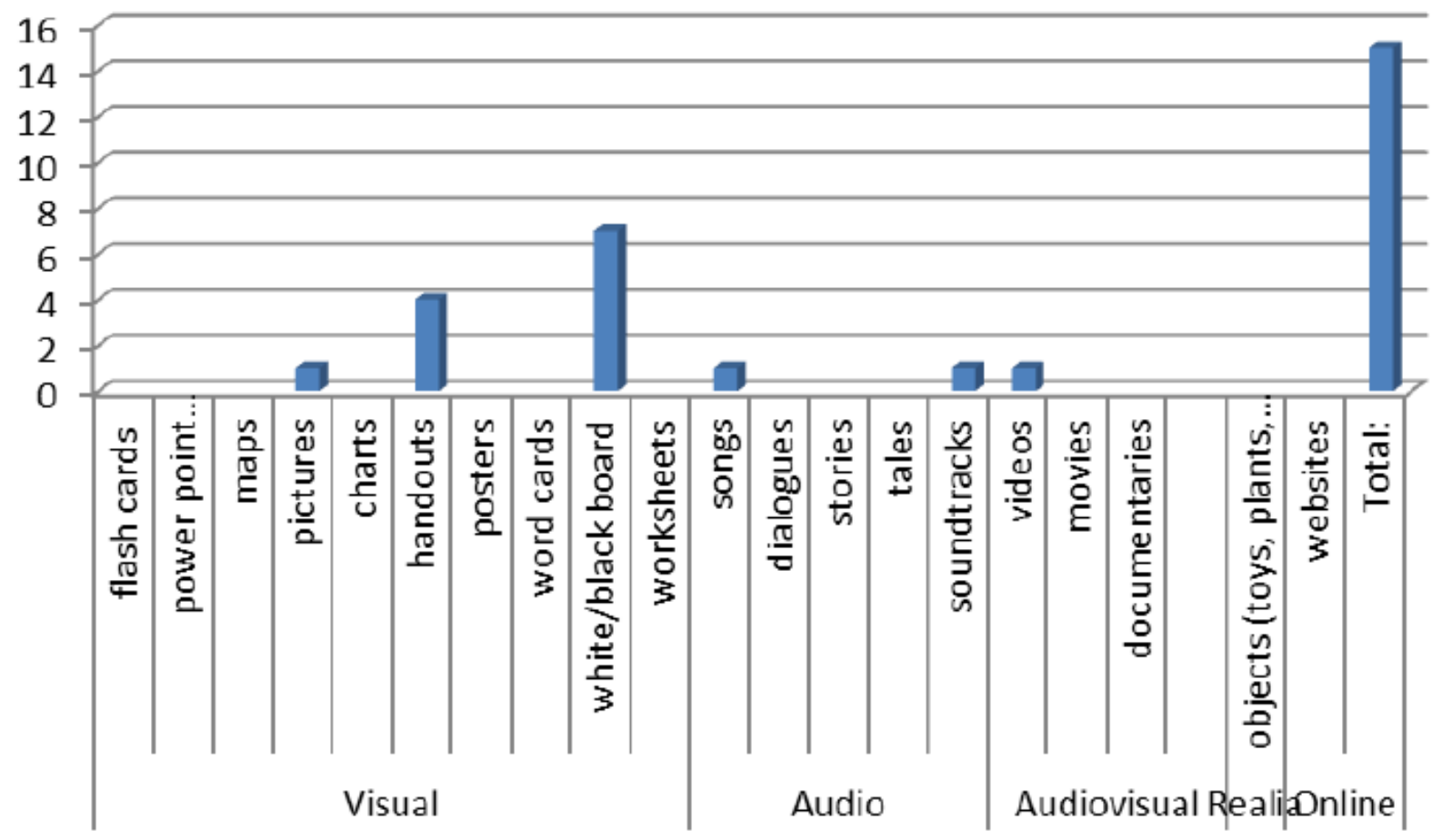

Graphic 4

Chart \# 4 represents the frequency of the use of the supplementary materials with the ten year-old students. According to this chart, we can see that the whiteboard was used 7 times throughout the 10 observed classes; handouts were used 4 times; pictures, songs, soundtracks and videos were used one time each; the total amount of frequency of the materials used during the 10 observed classes was 17; therefore, 17 times were supplementary materials used throughout the 10 observed classes of the learners.

The whiteboard and handouts were the materials that were used the most in these 10 class-observations. The least supplementary materials used were: pictures, songs, soundtrack and 


\section{The Use of Supplementary Materials for Teaching Children in EFL Classes}

Vol. 2, núm. 4., (2018)

Nefi Manuel Galán Cherrez; Jeimi Patricia Maya Montalvan; Oswaldo Edison Garcia Brito; Steffany Katherine Montece Ochoa

videos, but nevertheless, they were the most interesting and fun for the learners; with these materials they got involved in the class and enjoyed being part of it. They had a good time singing, listening and watching videos. According to the pupils' opinions it nice to have a break from the textbooks to sing a song or watch a video.

When it comes to implementing supplementary materials in a class, it is essential to have in mind the students' expectations and interests. While some materials, like the white board are easier to use, some others are a lot more suitable for a class of children, since they enjoy them and start to engage in the activities of the class.

We believe that when the supplementary material is more creative and used in a good way, students engage to it better. Teachers must find the time to find out what their students like and feel comfortable with in class. Having feedback about the materials used in class can be a good idea to know what students want. Teachers have to be careful not to overuse the same material in every class; materials should be changed as frequent as possible to be able to meet the students' expectations.

\section{Conclusions.}

Most of the supplementary materials that were employed in the lessons were appropriate for the students' level and age and pertinent for the content of the lessons because the group courses were divided according to the age and level of the pupils and also because the educators figured out the ways of learning that the students had in order to give teach them in a way they can best absorb information and apply it in everyday life. 


\section{The Use of Supplementary Materials for Teaching Children in EFL Classes}

Vol. 2, núm. 4., (2018)

Nefi Manuel Galán Cherrez; Jeimi Patricia Maya Montalvan; Oswaldo Edison Garcia Brito; Steffany Katherine Montece Ochoa

The supporting material that was used the most was the whiteboard due to its availability and also because it is the most practical didactic tool for teaching. On the other hand, maps, videos, flashcards, songs, among other materials were used but not as frequent as the whiteboard was.

The supplementary materials were selected according to the content and objective of the class, each one of them such as: whiteboard, maps, videos, movies, word cards, songs, handouts, flashcards and pictures were presented to the class in order to reinforce and analyze the contents that had been taught and helped to get the students' attention.

According to the observations made in each classroom setting. The combination of using supplementary materials in certain lessons such as the whiteboard along with flashcards and handouts helped the teachers to have better results in achieving the objective of the class because this technique motivated students to participate more and learn English.

The materials used in class were appropriate for the students' level of English and age; the teachers made sure that their learners understood the vocabulary presented by the material and that it would address their age as well.

The supplementary materials used in each class were of a good quality, the word cards, flashcards and pictures were well elaborated and hard to be torn. In the case of movies, videos and songs, the quality was high as well because they were well recorded and easy to understand. 


\section{The Use of Supplementary Materials for Teaching Children in EFL Classes}

Vol. 2, núm. 4., (2018)

Nefi Manuel Galán Cherrez; Jeimi Patricia Maya Montalvan; Oswaldo Edison Garcia Brito;

Steffany Katherine Montece Ochoa

\section{Bibliography.}

Audrey, A. (2010). Benefits of teaching a foreign language in elementary school. Retrieved from http://www.brighthub.com/education/languages/articles

Ball, D., \& Cohen, D. (2007). The role of curriculum materials in teacher learning and instructional reform. Educational Researcher, 25, 6-8.

British Council (2010, September 8). Learning styles and teaching. Retrieved from http: //www.teachingenglish.org.uk/articles/learning-styles-teaching

Brown, H. (2001) Teaching by principles an interactive approach to language- pedagogy. New York: Longman Publishers

Education.com (2009, June 5). Teaching techniques for inattentive and overactive children. Retrieved from http: //www.education.com

Felder, R \& Henriques E. (1995). Learning and teaching styles in foreign and second language education: Learning Styles. Foreign Language Annals, 1, 21-31.

Funder Standing. (March 2008). Learning styles. Retrieved from http://www.funderstanding.com/content/learning-styles

Gardner, H. (1985). Linguistic factors and learner differences. Retrieved from http://www.egyankosh.ac.in/bitstream/12345789/26038/1/Unit3.pdf

Gower, R., Phillips, D., \& Walters, S. (2005). Teaching practice: A handbook for teachers in training. Oxford: Macmillan Education.

Harmer, J. (2007). How to teach English. Oxford: Pearson Education Limited.

Jonas, A. \& Chwo, G. (2010). Adopting supplementary materials to enhance listening and speaking strategy used by Taiwanese college EFL learners. Great Light Journal (59) 2541

Kartal, G. (2011). The use of audiobooks in EFL classes to improve reading and listening skills. Retrieved from http://www.iconte.org

Kelsen, B. (2002). Teaching EFL to the I Generation: A survey YouTube as Supplementary Material with College EFL Students in Taiwan. CALL-EJ, 10, 1-18.

Langton, N. (1999, April 13). Teaching English as a second language. Retrieved from http://www.ehow.com/way_5188543_teaching-english-second-language.html

Lo, M. (2011, January 26) How to use visual aids in teaching. Retrieved from 


\section{The Use of Supplementary Materials for Teaching Children in EFL Classes}

Vol. 2, núm. 4., (2018)

Nefi Manuel Galán Cherrez; Jeimi Patricia Maya Montalvan; Oswaldo Edison Garcia Brito; Steffany Katherine Montece Ochoa

http://www.ehow.com/how_4601500_use-audio_visual-aids-teaching.html

Mingli Xiao. (2007). An empirical study of using internet-based desktop videoconferencing in an EFL setting. Unpublished doctoral dissertation, University of Ohio.

Peacock, M. (1997). The effect of authentic materials on the motivation of EFL learners. ELT Journal, 51, 144-156.

Richards, J. (2001). Curriculum development in language teaching. New York: Cambridge University Press.

Rodriguez, L. (1980) English as a foreign language in our school. Cauce, 3, 307- 309

Saville, M. (2006). Introducing second language acquisition. New York: Cambridge University Press.

Shvoong. (2010, August 6). Definition and characteristics of supplementary materials. Retrieved from http://www.shvoong.com/social sciences/education/2032919-definitioncharacteristics-supplementary-material

Wisconsin $4 \mathrm{H}$ Community Clubs (2007). Implementing 4-h project experiences: teaching methods. Madison, WI: Author.

Woolfolk, A. (2007). Educational psychology. New York: Pearson Education, Inc. 